\title{
PENGARUH SISTEM INFORMASI MANAJEMEN KEPEGAWAIAN TERHADAP PERENCANAAN SUMBER DAYA MANUSIA PADA BADAN KEPEGAWAIAN DAERAH KABUPATEN SIKKA
}

\author{
Yohanes Jibrail Mado ${ }^{1}$, Theresia Wihelmina Mado² \\ ${ }^{1}$ Program Studi Manajemen, Universitas Nusa Nipa, Maumere \\ ${ }^{2}$ Program Studi Teknik Informatika, Universitas Nusa Nipa, Maumere \\ E-mail : theresia.mado@gmail.com
}

\begin{abstract}
The purpose of this study is to find out whether there is the influence of the Civil Service Management Information System on Human Resource Planning at the Regional Personnel Agency of Sikka District. The design of the research used is descriptive and comparative causal research through surveys. The purpose of descriptive research is to make a systematic, factual and accurate explanation of the facts and characteristics of a particular population or region. The technique of data collection is done by spreading questionnaires to $n$ respondents to get answers that are in accordance with the research variables, as material to prove the proposed hypothesis. The sample in this study were 54 people. From the results of this study it was found that SIMPEG had a significant effect on HR planning in the Sikka City Personnel Agency. This study recommends that the Sikka District Personnel Agency that in implementing HR Planning can be carried out properly, if using accurate and accurate information. Such accurate and accurate information can be generated if SIMPEG supporting indicators are adequate and together work at the expected level.
\end{abstract}

Keywords: Personnel Management Information System, Human Resource Planning

\section{PENDAHULUAN}

\subsection{Latar Belakang}

Dewasa ini informasi dianggap sebagai salah satu faktor dalam lembaga atau instansi, karena merupakan piranti penting yang dapat memecahkan berbagai bentuk ketidaktahuan dan ketidakpastian yang seringkali menjadi kendala dalam proses pengambilan keputusan. Oleh sebab itu dibutuhkan suatu Sistim informasi yang selain dapat melakukan semua pengolahan data juga berfungsi untuk manajemen sehingga keputusan dapat diambil dengan lebih efektif dan efisien. Gagasan informasi demikian itu disebut dengan Sistim informasi manajemen atau manajemen yang mengatur Sistim informasi agar lebih mudah dijalankan.

Menurut Davis, Sistim informasi manajemen adalah manusia atau mesin yang terpadukan untuk menyajikan informasi guna mendukung fungsi operasi, manajemen, dan pengambilan keputusan dalam suatu organisasi ( Sunyoto, 2014:5).

Tujuan dibentuknya Sistim informasi manajemen adalah supaya organisasi memiliki informasi yang bermanfaat dalam membuat keputusan managemen, baik yang menyangkut keputusan-keputusan rutin maupun keputusankeputusan strategis.Sehingga Sistim informasi manajemen adalah suatu Sistim yang menyediakan kepada pengelola organisasi data maupun informasi yang berkaitan dengan pelaksanaan tugas-tugas organisasi (Sunyoto, 2014:19).

Implikasi utama penerapan SIM bagi masyarakat adalah komputer akan menurunkan harga produk. Komputer secara drasticakan menurunkan biaya klerikal dan pengolahan data, dan juga meningkatkan efisiensi pengendalian kegiatan manufacturing serta sangat membantu dalam perancangan desain. Tanpa komputer, biaya barang konsumsi akan 10\% lebih besar, dan bagi produk lainnya akan mencapai 50\% lebih besar. Kecenderungan kearah penurunan biaya melalui komputer diharapkan akan berlangsung terus di masa depan dan salah satu peran manager adalah mencari peluang penerapan komputer yang lebih luas demi menurunkan biaya dalam penyediaan produk dan jasa bagi para pelanggan organisasi (Scott, 1994).

Namun, teknologi komputer merupakan faktor penting dalam perkembangan Sistim informasi manajemen tetapi juga penghambat kemajuannya.Tanpa kemampuan komputer, konsep Sistim informasi manajemen tidak dapat diwujudkan.Adanya kemampuan perangkat keras dan lunak komputer meningkatkan pemakaiannya dalam rancangan Sistim informasi. Tetapi disamping itu perkembangan perangkat keras dan perangkat lunak tidak berjalan secara bersama ( Sunyoto, 2014:5).

Pada dasarnya, penerapan SIM berbasis komputer adalah untuk membuat efisiensi yang 
dapat menyediakan sumber-sumber operasi manajemen sehari-hari yang berhubungan dengan perencanaan taktis dan pengambilan keputusan yang mengendalikan manajemen dan perumusan kebijakan.

Berdasarkan pengertian sederhana tentang Sisitem Informasi Manajemen berbasis komputer diatas maka dapat disimpulkan bahwa SIM akan berpengaruh terhadap kinerja pegawai. Jika SIM berbasis komputer dapat diaplikaskan dengan baik diharapkan kinerja pegawai akan meningkat. Menurut Payaman Simanjuntak (2000) kinerja adalah tingkat pencapaian hasil atas pelaksanaan tugas tertentu.Dengan demikian kinerja merupakan suatu fungsi dari motivasi dan kemampuan. Untuk menyelesaikan tugas atau pekerjaan seseorang sepaturnya memiliki kesediaan dan tingkat kemampuan tertentu ( Rivai, 2014:406).

Ferguson (1997) menyatakan bahwa kualitas dan kuantitas dari serangkaian pekerjaan secara keseluruhan merupakan komponen utama dalam estimasi kinerja. Secara definisi operasional, kinerja mengkombinasikan efisiensi pekerja (atau seberapa cepat mereka menyelesaikan pekerjaan) dan efektivitas (atau seberapa baik mereka menyelesaikan pekerjaan) pada suatu pekerjaan secara utuh.

Berdasarkan pernyataan para ahli diatas, maka penulis mengamsumsikan saalah satu hal yang dapat mempengaruhi kinerja karyawan adalah penerapan Sistim yang tepat dalam instansi atau organisasi itu sendiri, termasuk Sistim informasi manajemen berbasis komputer. Untuk kepentingan peneltian, peneliti melaksanakan peneltian di Badan Kepegawaian Daerah Kabupaten Sikka, karena BKD Kabupaten Sikka dalam periode yang lama masih menggunakan pemrosesan data secara manual karena kurangnya tenaga ahli yang dapat menjadi operator Sistim. Banyak data hilang dan tidak tersimpan dengan baik serta pemrosesannya memakan waktu yang panjang serta berbelit-belit.Tetapi karena tuntutan pelayanan yang harus selalu membaik, maka BKD perlu menerapkan SIM berbasis komputer. Dengan SIM, pegawai akan menghemat waktu, biaya dan tenaga dalam melaksanakan tugas kerjanya.

Sebagai bahan rujukan penelitian, penulis menggunakan jurnal yang disusun oleh Mannaria Harahap tahun 2010 dengan judul, "Pengaruh Komputer Base Information Sistim (CBIS) Terhadap Kinerja Karyawan Koperasi Agro Niaga Jabung." Persamaan dengan penelitian terdahulu dengan penelitian yang sedang dilaksanakan adalah pada variable SIM berbasis komputer dan kinerja pegawai.Rancangan penelitian yang digunakan adalah penelitian deskriptif yang dirancang untuk mengetahui hubungan atau komparasi diantara variable yang diteliti.Metode pengumpulan data dengan menggunakan kuisioner. Hasil penelitian Harahap menunjukkan bahwa CBIS berpengaruh terhadap Kinerja pegawai.

Penelitian kedua yang digunakan penulis adalah penelitian oleh Johanna Mudjiati pada tahun 2008 dengan judul, Studi Pengaruh Penggunaan Sistim Informasi Terhadap Kinerja Karyawan Fakultas Ekonomi Universitas Diponegoro Semarang." Pada variable SIM dan Kinerja dan dilaksanakan dengan metode deskriptif.Pada penelitian terdahulu yang dipergunakan sebagai bahan rujukan ini, penulis melakukan survei terhadap penggunaan Sistim informasi akademik yang berbasis internet(SIMAWEB) dan pengaruhnya terhadap kinerja karyawan dengan cara melakukan observasi dan wawancara secara mendalam untuk memperoleh informasi sebanyakbanyaknya dari semua responden atauinforman. Hasil penelitian menunjukkan bahwa penggunaan Sistim informasi akademik yang berbasis internet (SIMAWEB) berpengaruh signifikan terhadap kinerja karyawan .

Berdasarkan latar belakang tersebut penulis ingin menganalisa bagaimana penerapan SIM berbasis komputer terhadap peningkatan kinerja pegawai Badan Kepegawaian Daerah dengan judul penelitian, "Penerapan Sistim Informasi Managemen Berbasis Komputer Terhadap Kinerja Pegawai Badan Kepegawaian Daerah Kabupaten Sikka"

\subsection{Perumusan Masalah}

Identifikasi masalah dalam penelitian ini adalah peneliti ingin mengetahui penerapan sisitem informasi manajemen berbasis komputer dalam meningkatkan kinerja pegawai di Badan Kepegawaian Daerah Kabupaten Sikka. Peneliti ingin mengetahui bagaimana variable Sistim informasi managemen berbasis komputer yaitu hardware, software, database dan prosedur berpengaruh secara signifikan dalam meningkatkan kinerja pegawai kantor BKD Kabupaten Sikka.

\subsection{Tujuan Penelitian}

Berdasarkan latar belakang dan identifikasi masalah yang telah dijabarkan diatas, maka rumusan masalah yang diajukan dalam penelitian ini adalah:

a. Bagaimana deskripsi sistem informasi managemen berbasis komputer yang terdiri atas hardware, software, data base danprosedur serta kinerja pegawai di Badan Kepegawaian Daerah Kabupaten Sikka?

b. Apakah variabel sistim informasi managemen berbasis komputer yang terdiri atas hardware, software, data base danprosedurberpengaruh terhadapkinerja pegawai di Badan Kepegawaian Daerah Kabupaten Sikka?

c. Manakah dari variabel sistim informasi managemen berbasis komputer yang terdiri 
atas hardware, software, data base danproseduryang berpengaruh dominan terhadapkinerja pegawai di Badan Kepegawaian Daerah Kabupaten Sikka?

\subsection{Ruang Lingkup}

Ruang lingkup pada penelitian ini adalah:

1. Mendeskripsikan penerapan Sistim informasi manajemen (SIM) berbasis komputer terhadap peningkatan kinerja pegawai di Badan Kepegawaian Daerah di Kabupaten Sikka.

2. Mendeskripsikan variabel dominan dari Sistim informasi manajemen (SIM) berbasis komputer terhadap peningkatan kinerja pegawai di Badan Kepegawaian Daerah di Kabupaten Sikka.

\subsection{Lokasi Penelitian}

Penelitian dilakukan kantor Badan Kepegawaian Daerah Kabupaten Sikka, Propinsi Nusa Tenggara Timur. Pemilihan lokasi dilakukan secara purposive karena beberapa pertimbangan, diantaranya ialah:

Sistim Informasi Managemen berbasis komputer adalah basic skill yang harus dikuasai oleh pegawai Kemampuan operator SIM berbasis komputer di BKD Kabupaten Sikka dalam meningkatkan kinerja karyawan masih belum pernah dianalisis sebelumnya.

\section{METODE PENELITIAN}

\subsection{Sistim Informasi Manajemen}

\section{a. Pengertian Sistim Informasi Manajemen}

Menurut Kelly (dikutip oleh Danang, 2014: 12), Sistim informasi managemen adalah perpaduan sumber daya manusia dan sumber daya yang berlandaskan komputer yang menghasilkan kumpulan penyimpanan, perolehan kembali, komunikasi dan penggunaan data untuk tujuan operasi manajemen yang efisisen dan bagi perencanaan bisnis.

Menurut Davis (dikutip Sunyoto, 2014:5)Sistim informasi managemen adalah manusia/mesin yang terpadukan untuk menyajikan informasi guna mendukung fungsi operasi, manajemen, dan pengambilan keputusan dalam suatu organisasi

\section{b. Indikator Sistim informasi Manajemen (SIM)}

Model Sistim informasi menurut O'Brien (2010:32) yang menunjukkan kerangka konsep dasar untuk berbagai komponen dan aktivitas Sistim informasi. Sistim informasi bergantung pada sumber daya manusia (pemakai akhir dan pakar Sistim informasi), hardware (mesin dan media),software (program dan prosedur), data (dasar data dan pengetahuan), serta jaringan (media komunikasi dan dukungan jaringan) untuk melakukan input, pemrosesan, output, penyimpanan, dan aktivitas pengendalian yang mengubah sumber daya data menjadi produk informasi.

1) Sumber Daya Hardware

Konsep sumber daya pemrosesan informasi.Secara khusus, sumber daya ini meliputi tidak hanya mesin, seperti komputer dan perlengkapan lainnya, tetapi juga semua media data, yaitu objek berwujud tempat data dicatat, dari lembaran kertas hinggadisk magnetis atau optical.

2) Sumber Daya Software

Sumber daya software meliputi semua rangkaian perintah pemrosesan informasi. Konsep umum software ini meliputi rangkaian perintah operasi dengan hardwarekomputer yang disebut program, rangkaian perintah pemrosesan informasi yang disebut prosedur.

3) Sumber Daya Data Base

Data dapat berupa angka, huruf serta karakter lainnnya yang menjelaskan transaksi bisnis dan kegiatan serta entitas lainnya. Data teks berupa kalimat yang digunakan untuk menulis komunikasi, data gambar, seperti grafik dan angka-angka, Serta data dalam bentuk audio video.

\section{c. Elemen-Elemen Sistim Informasi}

1) Manusia

Manusia merupakan penentu dari keberhasilan Sistim informasi manajemen dan manusia yang memanfaatkan informasi yang dihasilkan SIM.Unsur manusia dalam hal ini adalah staffkomputer professional dan para pemakai. Manusia yang termasuk dalam SIM dalam organisasi secara umum dibedakan menjadi tiga macam, yakni:
a) Analis/Perancang Sistim
b) Programmer
c) Operator

2) Perangkat keras

Perangkat keras adalah perangkat atau peralatan yang tampak secara fisik atau terlihat mata yang terdiri dari input hardware, processing hardware, storage hardware dan output hardware.

a) Input Hardware

b) Processing Hardware

c) Storage Hardware

3) Perangkat lunak

Perangkat lunak merupakan program yang dibuat oleh pembuat program untuk menjalankan perangkat keras komputer. Perangkat lunak adalah program yang berisi kumpulan intruksi untuk melakukan proses pengolahan data. Berikut ini adalah macam perangkat lunak:

a) Perangkat Lunak Sistim Komputer

b) Perangkat Lunak Aplikasi

4) Database

Database adalah file yang berisi program dan data dibuktikan dengan adanya media penyimpanan secara fisik seperti disket, hard disk, magnetic tape, dan sebagainya. File juga meliputi keluaran tercetak dan catatan lain diatas kertas, mikro film, dan lain sebagainya. 


\section{5) Prosedur}

Prosedur adalah peraturan-peraturan yang menentukan operasi Sistimkomputer.

6) Jaringan komputer

Jaringan komputer adalah sebuah kumpulan komputer, printer dan peralatan lainnya yang terhubung dalam satu kesatuan.Informasi dan data bergerak melalui kabel-kabel atau tanpa kabel sehingga memungkinkan pengguna jaringan komputer untuk bertukar data.

7) Komunikasi data

Komunikasi data adalah merupakan bagian dari telekomunikasi yang secara khusus berkenaan dengan transmisi atau pemindahan data dan informasi antara komputer-komputer dan piranti lain dalam bentuk digital yang dikirimkan melalui media komunikasi data.

\subsection{Sistim Informasi Berbasis Komputer}

McLeod(2001)menyatakanbahwaaplikasiuta ma computer yang pertama adalahpengolahandata akuntansi. Aplikasitersebutlaludiikutioleh empat aplikasi lain :Sistim informasi manajemen, Sistim pendukung keputusan,kantorvirtual,dan Sistim berbasispengetahuan. Porsikomputer dalampengolahinformasiterdiridaribidangaplikasibe rbasis computer SIA, SIM, DSS, kantor virtual, dan Sistim berbasis pengetahuan. Jadi, bisa disimpulkan bahwa Sistim Informasi berbasis komputer adalah suatu Sistim yang mendasarkan prinsip kerjanya pada komputer.

\section{a. Pengertian Kinerja Pegawai}

Menurut Simanjuntak (200) kinerja adalah tingkat pencapaian hasil atas pelaksanaan tugas tertentu.Dengan demikian kinerja merupakan suatu fungsi dari motivasi dan kemampuan. Untuk menyelesaikan tugas atau pekerjaan seseorang sepaturnya memiliki kesediaan dan tingkat kemampuan tertentu ( Rivai, 2014:406).

\section{b. Faktor- faktor yang mempengaruhi Kinerja}

Dharma (2005: 33) mengemukakan bahwa terdapat empat faktor yang mempengaruhi kinerja karyawan, yaitu:

1) Pegawai, berkenaan dengan kemauan dan kemampuan dalam melaksanakan pekerjaan.

2) Pekerjaan, menyangkut desain pekerjaan, uraian pekerjaan dan sumber daya untuk melaksakan pekerjaan.

3) Mekanisme kerja, mencakup Sistim, prosedur pendelegasian dan serta organisasi.

4) Lingkungan kerja, meliputi faktor-faktor lokasi dan kondisi kerja, iklim organisasi dan komunikasi.

\section{c. Tujuan Penilaian Kinerja}

Suatu perusahaan melakukan penilaian kinerja didasarkan pada dua alasan pokok, yaitu(1) manager memerlukan evaluasi yang objektif terhadap kinerja karyawan pada masa lalu yang digunakan untuk membuat keputusan dibidang SDM dimasa datang; dan (2) manager memerlukan alat yang memungkinkan untuk membantu karyawannya memperbaiki kinerja, merencanakan pekerjaan, mengembangkan kemampuan dan keterampilan untuk perkembangan karier dan memperkuat kualitas hubungan antar manajemen yang bersangkutan dengan karyawannya.

\section{PROSEDUR PENELITIAN}

\subsection{Observasi}

Pengamatan merupakan alat pengumpulan data guna merumuskan nilai-nilai yang berlaku di masyarakat (Arikunto, 2013:272). Pengamatan yang dilakukan peneliti adalah menganalisa penerapan SIM berbasis komputer di BKD Kabupaten Sikka dalam meningkatkan kinerja karyawan.

\subsection{Dokumentasi}

Pada Penelitian ini, Penulis melakukan studi dokumen terhadap data sekunder untuk memperoleh landasan teoritis yang dapat digunakan untuk menganalisis penerapan SIM berbasis komputer di BKD Kabupaten Sikka dalam meningkatkan kinerja karyawan.

\subsection{Kuesioner}

Kuesioner teknik pengumpulan data dilakukan dengan menyembarkan kuesioner kepadan responden untuk mendapatkan jawaban yang sesuai dengan variabel penelitian, sebagai bahan pembuktian terhdapa hipotesis yang daijukan. Responden diminta untuk memberikan jawaban atau pendapat atas suatu pertanyaan, dimana masing-masing pertanyaan disediakan lima kemungkinan jawaban yang berada dalam satu kontinum yang diberi bobot sesuai dengan item, dan dalam penelitian ini bobotnya adalah satu sampai lima (1 sampai 5). Skala ini disebut skala Likert. Berikut ini aadalah contoh alternatif jawaban yang akan digunakan dalam kuisioner penelitian ini :

a. Jawaban Sangat Setuju (SS) dengan skor 5

b. Jawaban Setuju (S) dengan skor 4

c. Jawaban Netral (N) dengan skor 3

d. Jawaban Tidak Setuju (TS) dengan skor 2

e. Jawaban Sangat Tidak Setuju (STS) dengan skor 1

\begin{tabular}{|c|c|c|c|}
\hline \multicolumn{2}{|c|}{ Variabel } & indikator & Butir Pertanyaan \\
\hline \multirow[t]{2}{*}{$\begin{array}{l}\text { Sistim } \\
\text { Mana } \\
\text { jemen } \\
\text { Infor } \\
\text { masi } \\
(X)\end{array}$} & $\begin{array}{l}\text { Hard } \\
\text { ware } \\
\text { (X1) }\end{array}$ & $\begin{array}{l}\text { 1. Komputer } \\
\text { 2. perangkat }\end{array}$ & 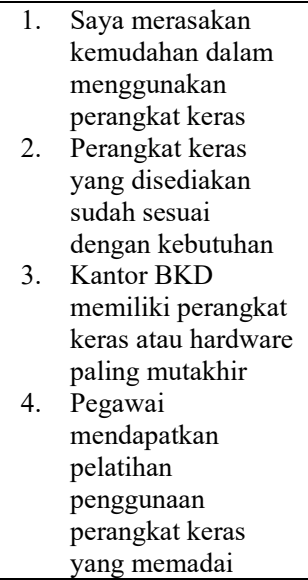 \\
\hline & $\begin{array}{l}\text { Soft } \\
\text { ware }\end{array}$ & $\begin{array}{l}\text { 1. Sistim } \\
\text { Operasi }\end{array}$ & $\begin{array}{lr}\text { 5. Saya merasakan } \\
\text { kemudahan } & \text { dalam }\end{array}$ \\
\hline
\end{tabular}




\begin{tabular}{|c|c|c|c|}
\hline & $(X 2)$ & 2. Aplikasi SIM & 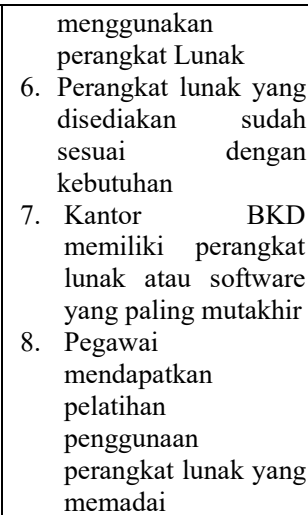 \\
\hline & $\begin{array}{l}\text { Data } \\
\text { base (X3) }\end{array}$ & $\begin{array}{l}\text { 1. Akurat } \\
\text { 2. Konsisten } \\
\text { 3. Berdaya guna }\end{array}$ & $\begin{array}{l}\text { 9. Penyimpanan data } \\
\text { yang dilakukan BKD } \\
\text { dalam memenuhi } \\
\text { kebutuhan pengguna } \\
\text { mudah dipahami } \\
\text { 10. } \begin{array}{l}\text { cara pengolahan } \\
\text { data mudah }\end{array} \\
\text { dilaksanakan } \\
\text { 11. Batas waktu } \\
\text { penyimpanan dan } \\
\text { Penggunaan data } \\
\text { sesuai dengan } \\
\text { kebutuhan } \\
\text { 12.Jenis data yang } \\
\text { disajikan melayani } \\
\text { kebutuhan para } \\
\text { pengguna }\end{array}$ \\
\hline & $\begin{array}{l}\text { Prosedur } \\
\text { (X4) }\end{array}$ & & 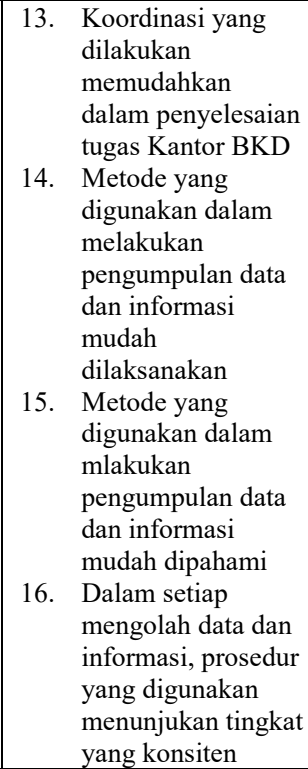 \\
\hline $\begin{array}{l}\text { Kiner } \\
\text { ja (Y) }\end{array}$ & \multicolumn{2}{|c|}{$\begin{array}{l}\text { 1. Peningkatan Kualitas } \\
\text { 2. Mempermudah pekerjaan } \\
\text { 3. Pekerjaan menjadi efisien } \\
\text { 4. Pekerjaan menjadi lebih } \\
\text { akurat } \\
\text { 5. Peningkatan produktifitas } \\
\text { 6. Mempermudah pekerjaan }\end{array}$} & 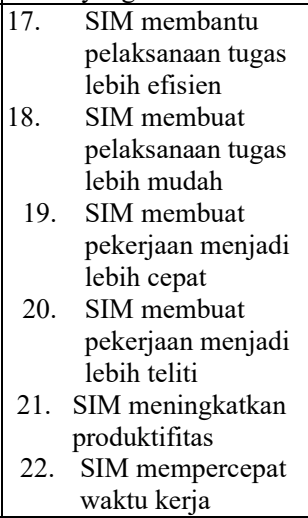 \\
\hline
\end{tabular}

3.6 Populasi dan Teknik Pengambil Sampel

\section{Populasi}

Populasi adalah wilayah generalisasi yang terdiri dari objek dan subjek yang menjadi kuantitas dari karekteristik tertentu yang diterapkan oleh peneliti untuk dipelajari dan kemudian ditarik kesimpulan (Sugiyono,1997:57). Populasi dalam penelitian ini adalah seluruh staff Badan Kepegawaian Daerah Kabupaten Sikka berjumlah 34 orang.

\section{Sampel}

Singarimbun (1995:105) menyatakan bahwa untuk menentukan jumlah sampel digunakan metode yang representative di mana karakterisitik yang terdapat pada sampel yang terbatas itu bena-benar menggambarkaan kondisi yang sebenarnya dalam keseluruhan dari populasi.

Sebagaimana yang dikemukakan oleh Arikunto (2012:57), apabila subyek yang diteliti kurang dari 100 maka lebih baik subyek tersebut diambil seluruhnya, tetapi apabila subyek tersebut melebihi 100 maka subyek tersebut dapat diambil 10-15\% atau 20-25\%.Jadi, sampel yang diambil yang digunakan dalam penelitian ini adalah 34 orang.

Tabel 3.2 Penyebaran Responden Berdasarkan Unit Kerja

\begin{tabular}{|c|c|}
\hline Unit & $\begin{array}{c}\text { Jumlah } \\
\text { Peoawai } \\
9\end{array}$ \\
\hline Sekretariat & 6 \\
\hline Bidang Formasi dan Informasi & 7 \\
\hline Bidang Mutasi & 6 \\
\hline Bidang Pendidikan dan Pelatihan & 6 \\
\hline $\begin{array}{c}\text { Bidan Kesejahteraan dan Pebinaan } \\
\text { Disinlin neoawai } \\
\text { TOTAL }\end{array}$ & $\mathbf{3 4}$ \\
\hline
\end{tabular}

Sumber : Data sekunder di olah 2015

\subsection{Metode Analisis Data}

Sejalan dengan tujuan penelitian dan rumusan hipotesis, maka analisis data yang dipergunakan dalam penelitian ini adalah:

\section{Analisis Dengan Model Regresi Linear Berganda}

Merupakan analisis yang bersifat kuantitatif digunakan untuk membuktikan hipostesis penelitian model ini dipilih karena penulis ingin mengetahui seberapa besar penerapan Sistim Informasi Manajemen berbasis komputer terhadap kinerja pegawai dengan model analisis regresi linear berganda yang dibantu dengan perhitungan komputer SPSS Versi 19 maka besarnya pengaruh variabel independen tersebut dapat diketahui.

\section{a. Uji Model Regresi}

Model regresi yang digunakan untuk menguji hipotesis penelitian seperti setelah dikemukakan adalah regresi liniear berganda, yakni

$Y=\alpha+\beta_{1} X_{1}+\beta_{2} X_{2}+\beta_{3} X_{3}+\beta_{4} X_{4}+e$ Dimana :

$$
\begin{aligned}
& \mathrm{Y} \\
& \alpha: \text { Konstanta } \\
& \mathrm{X} 1 \mathrm{:} \text { Hardware } \\
& \mathrm{X} 2 \quad \text { : Software }
\end{aligned}
$$




\author{
X3 : Database \\ X4 : Prosedur \\ $b_{1}, b_{2}, b_{3}$ : Koefisien Parsial Regresi \\ e : Variabel Pengganggu
}

\section{Koefisien Determinasi $\left(\mathbf{R}^{2}\right)$}

Koefisien determinasi yaitu alat analisis yang digunkan untuk mengetahui besarnya sumbangan variabel bebas secara simultan terhadap naik turunnya variabel terikat.Kegunaan dari variabel koefisien determinasi adalah untuk mengukur ketepatan yang paling baik dari analisis regresi. Semakin besar $\mathbf{R}^{2}$, berarti semakin tepat persamaan perkiraan regresi linear berganda tersebut dipakai sebagai alat untuk peramalan, yang dapat dirumuskan sebagai berikut :

$$
\text { Sum of Square Regression }
$$

$\mathrm{R} 2=$ Sum of Square Total

\section{Analisis Koefisien Korelasi}

Analisis koefisien korelasi berganda (R) untuk mengetahui keeratan hubungan antara variabel terikat dengan analisis koefisien korelasi berganda dibantu hasil output SPSS Versi 19. Analisis korelasi parsial $\left(\mathrm{r}^{2}\right)$ digunakan untuk mengetahui pengaruh atau proposi variabel terikat yang dapat dijelaskan oleh variabel bebas secara parsial.Sedangkan analisis koefisien parsial (r) digunakan untuk mengetahui kuat tidaknya hubungan atau korelasi antara variabel bebas dengan variabel terikatnya dengan membandingkan koefisien parsial $\left(\mathrm{r}^{2}\right)$ dibantu output SPSS Versi 19.

1. Teknik Analisa Data

1. Analisis Deskriptif

Dipergunakan untuk menerangkan informasi mengenai responden, serta untuk mengetahui deskripsi Sistem Informasi Manajemen Kepegawaian dan Perencanaan Sumber Daya Manusia.Penyajian data penelitian dalam bentuk table frekuensi dan pengukuran nilai-nilai statistik seperti nilai maksimum, minimum, mean dan standard deviasi.

2. Analisis Dengan Model Regresi Linear Berganda

Merupakan analisis yang bersifat kuantitatof digunakan untuk membuktikan hipostesis penelitian model ini dipilih karena penulis ingin mengetahui seberapa besar pengaruh Sistem Informasi Manajemen Kepegawaian terhadap perencanaan sumber daya manusia dengan model analisis regresi linear berganda yang dibantu dengan perhitungan komputer SPSS Versi 19 maka besarnya pengaruh variabel independen tersebut dapat diketahui.

$$
\begin{aligned}
& \text { a. Uji Model Regresi } \\
& \text { Model regresi yang digunakan } \\
& \text { untuk menguji hipotesis penelitian } \\
& \text { seperti setelah dikemukakan adalah } \\
& \text { regresi liniear berganda, yakni : } \\
& \mathrm{Y}=\alpha+\beta 1 \mathrm{X} 1+\beta 2 \mathrm{X} 2+\beta 3 \mathrm{X} 3+\beta 4 \mathrm{X} 4+\varepsilon \\
& \text { Dimana : } \\
& \mathrm{Y}: \text { Perencanaa Sumber Daya } \\
& \text { Manusia }
\end{aligned}
$$

$$
\begin{array}{lll}
\alpha & \text { : Konstanta } & \\
\mathrm{X} 1 & \text { : Hardware } & \\
\mathrm{X} 2 & \text { : Software } & \\
\mathrm{X} 3 & \text { : Database } & \\
\mathrm{X} 4 \quad \text { : Prosedur } & \\
\mathrm{b} 1, \mathrm{~b} 2, \mathrm{~b} 3, \mathrm{~b} 4, & \text { :KoefisienParsial } \\
\text { Regresi } & \\
\mathrm{e} \quad \text { : Variabel Pengganggu }
\end{array}
$$

b. Koefisien Determinasi (R2)

Koefisien determinasi yaitu alat analisis yang digunkan untuk mengetahui besarnya sumbangan variabel bebas secara simultan terhadap naik turunnya variabel terikat.Kegunaan dari variabel koefisien determinasi adalah untuk mengukur ketepatan yang paling baik dari analisis regresi. Semakin besar R2, berarti semakin tepat persamaan perkiraan regresi linear berganda tersebut dipakai sebagai alat untuk peramalan, yang dapat dirumuskan sebagai berikut :

$$
R^{2}=\frac{\text { Sum of Square Regression }}{\text { Sum of Square Total }}
$$

c. Analisis Koefisien Korelasi

Analisis koefisien korelasi berganda (R) untuk mengetahui keeratan hubungan antara variabel terikat dengan analisis koefisien korelasi berganda dibantu hasil output SPSS Versi 19. Analisis korelasi parsial (r2) digunakan untuk mengetahui pengaruh atau proposi variabel terikat yang dapat dijelaskan oleh variabel bebas secara parsial.Sedangkan analisis koefisien parsial (r) digunakan untuk mengetahui kuat tidaknya hubungan atau korelasi antara variabel bebas dengan variabel terikatnya dengan membandingkan koefisien parsial (r2) dibantu output SPSS Versi 19.

d. Uji Asumsi Klasik

Uji Asumsi Klasik dapat dibedakan menajadi :

1) Uji Multikolinearitas

Model regresi mengasumsikan tidak adanya multikolinearitas atau tidak adanya hubungan yang sempurna antara variabel bebas yang satu dengan variabel bebas lainnya.Untuk mendeteksi ada tidaknya multikolinearitas dapat dilakukan dengan melihat nilai VIF (Varience Inflation Factor) antara variabel-variabel bebas (Santoso, dalam Kusumawati 2003).

2) Uji Heterokedasitas

Heterokedasitas berarti varian residual tidak sama untuk semua pengamatan, semakin besar residual untuk pengamataan yang semakin banyak. Model regresi linear mengasumsikan bahwa varian variabel residual bersifat konstan 
atau sama untuk berbagi pengamatan.

3) Uji Autokorelasi

Autokorelasi adalah gejala adanya korelasi serial diantara keselahan pengganggu (residual), sehingga munculnya suatu data dipengaruhui oleh data sebelumnya (Ghozali, dalam Kusumawati 2003:46). Untuk mendeteksi terhadap gejala autokorelasi dilakukan dengan pengujian Durbin Watson (d) yang membandingkan nilai $\mathrm{d}$ table pada $\alpha=0,05$.

\section{HASIL DAN PEMBAHASAN}

\subsection{Karakteristik Responden}

Responden dalam penelitian ini adalah karyawan yang terlibat langsung pada penggunaan komputer sejumlah 34 orang personil, dengan karateristik menurut: jenis kelamin, tingkat pendidikan, umur, dan masa kerja, seperti disajikan sebagai berikut:

a. Responden berdasarkan jenis kelamin Tabel 4.1 Responden Berdasarkan Jenis Kelamin

\begin{tabular}{|c|c|c|}
\hline $\begin{array}{c}\text { Jenis } \\
\text { Kelamin }\end{array}$ & Jumlah & $\begin{array}{c}\text { Persentase } \\
\mathbf{( \% )}\end{array}$ \\
\hline Laki-Laki & 24 & 70,5 \\
\hline Perempuan & 10 & 29,5 \\
\hline Total & 34 & $100 \%$ \\
\hline
\end{tabular}

Sumber : Data Sekunder di olah 2016

Berdasarkan tabel diatas, dapat diketahui bahwa operator atau pemakai komputer di badan Kepegawaian Daerah Kabupaten Sikka terbanyak adalah 70,5\% adalah berjenis laki-laki sedangkan sisanya $29,5 \%$ adalah perempuan.

Tabel 4.2Responden Berdasarkan Pendidikan

\begin{tabular}{|c|c|c|}
\hline Pendidikan & Jumlah & Persentase (\%) \\
\hline S1 & 9 & 26,47 \\
\hline D3 & 1 & 2,9 \\
\hline D1 & 1 & 2,9 \\
\hline SMA & 23 & 68,33 \\
\hline Total & 34 & $100 \%$ \\
\hline
\end{tabular}

Sumber : Data Sekunder di olah 2016

Berdasarkan tabel diatas dapat diketahu jenjang pendidikan personil Badan kepegawaian daerah Kabupaten Sikka, yaitu: sebanyak 23 orang atau $68,33 \%$ berpendidikan SMA sederajat, 9 orang atau 26, 47\% berpendidikan S1 dan masing-masing satu orang atau 2, $9 \%$ dari D3 dan D1.

b Responden berdasarkan umur dan masa jabatan

\begin{tabular}{|l|l|l|}
\hline Umur & Jumlah & Persentase (\%) \\
\hline
\end{tabular}

\begin{tabular}{|c|c|c|}
\hline$<25$ & 12 & 35,2 \\
\hline $25-40$ & 19 & 55,8 \\
\hline $40-47$ & 7 & 20,5 \\
\hline Total & 34 & Persentase (\%) \\
\hline $\begin{array}{c}\text { Masa } \\
\text { Kerja }\end{array}$ & Jumlah & 8,8 \\
\hline$<5$ & 3 & 14,7 \\
\hline $5-10$ & 5 & 35,2 \\
\hline $10-20$ & 12 & 41,17 \\
\hline $20-27$ & 14 & $100 \%$ \\
\hline Total & 34 & \\
\hline
\end{tabular}

Sumber : Data Sekunder di olah 2016

Karateristik responden berdasrakan usia dapat dilihat bahwa mayoritas responden $55 \%$ berusia antara 25- 40 sedangkan 12 atau 35,2 \%orang responden berusia $<25$. Berdasarkan masa kerja, persentase masa kerja terlama adalah 20-27 dengan $41,17 \%$.

1. Uji validitas dan reliabilitas

a. Uji Validitas

Suatu alat ukur dikatakan valid jika mampu mengukur apa yang hendak diukur dan dapat mengungkapkan data dari variable yang diteliti secara tepat. Teknis yang digunakan untuk uji validitas adalah korelai product moment pada taraf signifikasi $0.05 \%$ dengan cara mengkorelasikan skor masing-masing item dengan skor tptalnya. Hasil pengukuran validitas tersebut disajikan dalam tabel berikut ini:Suatu item dinyatakan valid jika koefisien korelasi product moment pearson $(r) \geq 0,26$. Hasil pengukuran validitas disajikan pada tabel berikut :

Tabel 4.4 Uji Validitas Item Instrumen

\begin{tabular}{|c|c|c|c|}
\hline Item & $\begin{array}{c}\text { Koefisien } \\
\text { Korelasi }\end{array}$ & $\begin{array}{c}\text { Nilai r tabel } \\
\alpha=0,05\end{array}$ & Ket \\
\hline X1.1 & 0.843 & 0,26 & Valid \\
\hline X1.2 & 0.729 & 0,26 & Valid \\
\hline X1.3 & 0,726 & 0,26 & Valid \\
\hline X1.4 & 0,599 & 0,26 & Valid \\
\hline X2.1 & 0,704 & 0,26 & Valid \\
\hline X2.2 & 0,543 & 0,26 & Valid \\
\hline X2.3 & 0,763 & 0,26 & Valid \\
\hline X2.4 & 0,632 & 0,26 & Valid \\
\hline X3.1 & 0,773 & 0,26 & Valid \\
\hline X3.2 & 0,716 & 0,26 & Valid \\
\hline X3.3 & 0,643 & 0,26 & Valid \\
\hline X3.4 & 0,672 & 0,26 & Valid \\
\hline X4.1 & 0,704 & 0,26 & Valid \\
\hline X4.2 & 0,703 & 0,26 & Valid \\
\hline X4.3 & 0,735 & 0,26 & Valid \\
\hline X4.4 & 0,791 & 0,26 & Valid \\
\hline
\end{tabular}




\begin{tabular}{|c|c|c|c|}
\hline Y1 & 0,730 & 0,26 & Valid \\
\hline Y2 & 0,744 & 0,26 & Valid \\
\hline Y3 & 0,717 & 0,26 & Valid \\
\hline Y4 & 0,709 & 0,26 & Valid \\
\hline Y5 & 0,517 & 0,26 & Valid \\
\hline Y6 & 0,754 & 0,26 & Valid \\
\hline
\end{tabular}

Sumber : Data primer di olah 2016

Berdasarkan hasil uji validitas yang dilakukan terhadap item instrument yang digunakan dalam penelitian., menunjukan bahwa semua item instrument penelitian yang digunakan dapat dikatakan valid, karena telah memenuhi kriteria pengujian vaaliditas item instrument yang digunakan yaitu nilai indeks korelasi Product Moment Pearson $(r) \geq 0,26$.

\section{b. Uji reliabilitas}

Uji realibilitas bertujuan untuk menguji konsistensi alat ukur yang digunakan.Uji reliabilitas butir pertanyaan pada penelitian ini menggunakan rumus Alpha Cronbanch. Instrument dinyatakan valid apabila nilai Alpha Cronbach lebih besar atau sama dengan 0,60. Adapun hasil uji realibilitas masingmasing variabel dapat disajikan pada tabel 4.8

Tabel 4.5 Uji Realibilitas Item Instrumen

\begin{tabular}{|c|c|c|c|}
\hline Item & $\begin{array}{c}\text { Koefisien } \\
\text { Realibilitas }\end{array}$ & $\begin{array}{c}\text { Nilai } \\
\text { Rekomendasi }\end{array}$ & Keterangan \\
\hline $\mathrm{Y}$ & 0,7610 & 0,60 & Realiabel \\
\hline $\mathrm{X} 1$ & 0,7368 & 0,60 & Realiabel \\
\hline $\mathrm{X} 2$ & 0,8573 & 0,60 & Realiabel \\
\hline $\mathrm{X} 3$ & 0,7593 & 0,60 & Realiabel \\
\hline $\mathrm{X} 4$ & 0,8354 & 0,60 & Realiabel \\
\hline
\end{tabular}

Sumber : Data primer di olah 2016

\section{A. Analisis hasil Penelitian}

\section{Hasil Analisis Deskriptif}

Penelitian ini menggunakan empat variable bebas dan satu variable terikat.Masingmasing variable dideskripsikan berdasarkan jawaban yang telah diberikan oleh responden pada questioner. Deskripsi dari masing-masing variable tersebut dapat diuraikan sebagai berikut:

a. Hardware (X1)

Tabel 4.6 Distribusi Frekuensi Variabel Hardware (XI)

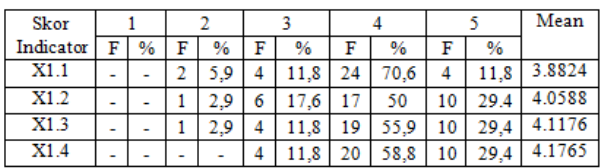

b. Software (X2)

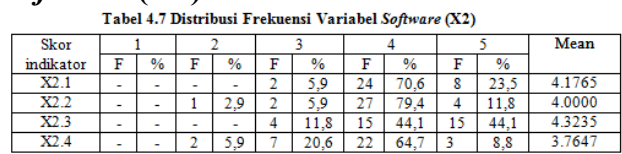

c. Database(X3)

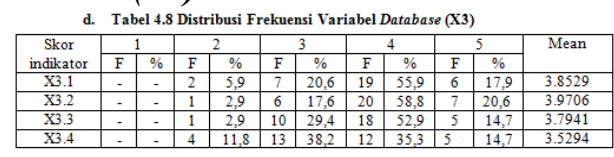

a. Uji Multikolinieritas
Multikolinieritas adalah adanya hubungan linier yang sempurna atau pasti antara variabel independen.Pengujian multikolinieritas pada penelitian ini menggunkan nilai VIF (Varience Inflation Factor) yang diperoleh dari pengujian hipotesis. Apabila nilai VIF lebih kecil dari 5 berarti tidak terjadi multikolinieritas antara variabel independen (Santoso,2004). Hasil pengujian asumsi multikolinieritas ini disajikan pada Tabel 4.20 berikut :

\begin{tabular}{|c|c|c|c|}
\hline \multicolumn{4}{|c|}{ Tabel 4.11 Hasil pengujian Multikolinieritas.Model Regresi } \\
\hline No & Item & $\begin{array}{c}\text { Nilai } \\
\text { VIF }\end{array}$ & Keterangan \\
\hline 1 & Brainware (X1) & 1,584 & Tidak Terdapat Multikolinientas \\
\hline 2 & Hardware (X2) & 4,364 & Tidak Terdapat Multikolinientas \\
\hline 3 & Software (X3) & 1,964 & Tidak Terdapat Multikolinientas \\
\hline 4 & \multicolumn{4}{|c|}{ Data (X4) } & 3,788 & Tidak Terdapat Multikolinientas \\
\hline \multicolumn{4}{|c|}{ Sumber:Data Primer diolah 2016 } \\
\hline
\end{tabular}

\section{a. Uji Heteroskedasitas}

Uji heteroskedasitas bertujuan menguji apakah dalam model regresi terjadi ketidasamaan varian pengganggu (residual), tidak berbeda dari satu penelitian ke penelitian berikutnya. Pengujian dilakukan dengan cara membaca grafik plot (scatterplot) berdasarkan pendapat Ghozali (2001:71), menyatakan jika ada pola tertentu seperti titik-titik yang membentuk pola tertentu yang tidak teratur, maka dapat diidentifikasi telah terjadi heteroskedasitas. Teknik yang digunakan untuk mengetahui heteroskodesitas adalah dengan menggunkan grafik plot (Scatterplot) antara nilai grafik plot disajikan seperti pada gambar 4.1berikut :

Scatterplot

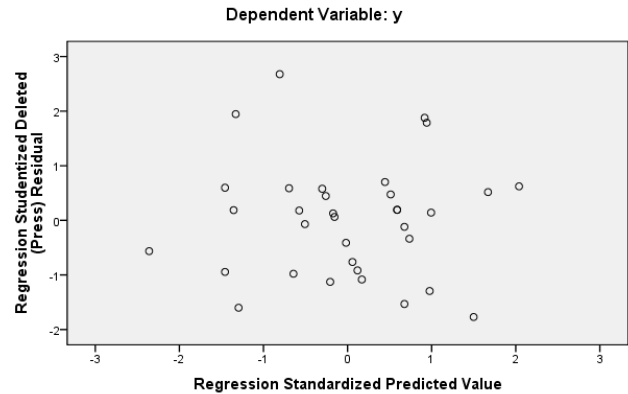

Berdasarkan hasil grafik plot menunjukan bahwa penyebaran ploting $\mathrm{Z}$ predictor dan $\mathrm{S}$ residual tidak membentuk suatu pola tertentu. Hal ini berarti tidak terjadi heterokedesitas.

\section{b. Uji Autokorelasi}

Hasil uji auto korelasi akan dilakukan berdasarkan nilai Durbin Watson. Jika DWuper < DWstatistik < 4-DWuper maka model regresi bebas dari permasalahan autokorelasi. Sebaliknya, jika DWuper $<$ DWstatistik < 4-DWlower maka model regresi mengandung masalah autokorelasi (Gujarati,1995). Hasil perhitungan statistik dengan jumlah varibel bebas $(\mathrm{k})=5$, jumlah sampel $(\mathrm{n})=$ 34 diperoleh angka durbin Watson sebesar 1,884 Nilai DW berada du $=0,193$ dan 4 -DU $=2,077$ artinya tidak terjadi autokorelasi. 


\section{Uji Hipotesis}

Berdasarkan rumusan masalah dan tujuan penelitian, maka hipotesis yang diajukan dalam penelitian ini adalah:

1. Hipotesis pertama menyatakan: Didugavariabel sistim informasi managemen berbasis komputer berpengaruh terhadap peningkatan kinerja pegawai kantor Badan Kepegawaian Daerah Kabupaten Sikka. Hasil perhitungan statistik yang dilaksanakan hasilnya:

Tabel 4.14 ANOVA $^{\mathrm{b}}$

\begin{tabular}{|l|r|r|r|r|r|}
\hline Model & Sum of Squares & df & $\begin{array}{c}\text { Mean } \\
\text { Square }\end{array}$ & F & Sig. \\
\hline Regression & 217.616 & 4 & 54.404 & 97.699 & $.000^{3}$ \\
Residual & 16.149 & 29 & 557 & & \\
\hline Total & 233.765 & 33 & & & \\
\hline
\end{tabular}

a. Predictors: (Constant), $\mathrm{x} 2, \mathrm{x} 1, \mathrm{x} 3, \mathrm{x} 4$

b. Dependent Variable: $y$

Berdasarkan hasil uji f sebesar 97.699 dengan taraf signifikasi 0,000 hal ini menunjukkan bahwa hipotesis diterima, artinya variable sistim informasi managemen berbasis komputerynag terdiri dari Hardware, Software, Database dan prosedur secara bersama-sama berpengaruh terhadap kinerja pegawai Badan Kepegawaian Daerah Kabupaten Sikka.

Diduga terdapat variabel sistim informasi managemen berbasis komputer yangberpengaruh dominan terhadap peningkatan kinerja pegawai kantor Badan Kepegawaian Daerah Kabupaten Sikka. Berdasarkan hasil uji model linear untuk mencari pengaruh yang paling besar diantara variable sistim Informasi managemen berbasis komputer didapatkan hasil tertinggi adalah pada variable Hardware(X1). Sehingga dapat disimpulkan bahwa Hardware adalah variable yang berpengaruh dominan terhadap kinerja pegawai di badan Kepegawaian Kabupaten Sikka.

\begin{tabular}{|c|c|r|c|c|}
\multicolumn{5}{c}{ Tabel 4.15 Hasil Uji Koefisien Korelasi Secara Parsial } \\
\hline Variabel & Koefisien Partial & \multicolumn{1}{c|}{ T Hitung } & \multicolumn{1}{c|}{ Sig. } & Keterangan \\
\hline X1 & 7,940 & 7.029 & .000 & Signifikan \\
\hline X2 & 5,360 & 3.419 & .000 & Signifikan \\
\hline X3 & 4,270 & 2.543 & .000 & Signifikan \\
\hline X4 & 4,380 & 2.620 & .001 & Signifikan \\
\hline
\end{tabular}

\section{B. Pembahasan Hasil Penelitian}

Hasil uji hipotesis menunjukan bahwa Sistim Informasi Manajemen berbasis komputer yang terdiri atas Hardware, Software, Database, prosedur dapat meningkatkan kinerja pegawai Pada Badan Kepegawaian Daerah Kabupaten Sikka sehingga model yang digunakan dapat diterima.

Kontribusi variabel bebas terhadap kinerja pegawai dapat dilakukan dengan melihat besarnya nilai koefisien determinan $\mathrm{r}^{2}$ yang menunjukan bahwa variabel bebas memberikan kontribusi pada penelitian ini sedangkan sisanya dipengaruhui oleh faktor lain yang tidak dijelaskan pada penelitian ini. Besarnya nilai koefisien korelasi berganda $\left(\mathrm{r}^{2}\right)$ adalah 0, 931 hal ini menunjukan bahwa besarnya hubungan Sistim Informasi Manajemen berbasis computer yang terdiri atas Hardware, Software, Data, dan prosedur terhadap kinerja pegawai di Badan Kepegawaian Kabupaten Sikka.

Analisis koefisien korelasi berganda (R) untuk mengetahui keeratan hubungan antara variable bebas secara serempak berpengaruh secara signifikan terhadap variable terikat.Adapaun koefisien korelasi sebesar berarti terdapat hubungan signifikan secara bersama-sama antara variabel bebas dengan variable terikat. Besarnya nilai koefisien korelasi berganda (R) pada penelitian ini adalah 0,965 hal ini menunjukan bahwa besarnya hubungan Sistim Informasi Manajemen berbasis komputer yang terdiri atas Hardware, Software, Database, dan prosedur terhadap kinerja pegawai di Badan Kepegawaian Kabupaten Sikka sebesar 0,965 Menurut Sugiyono (1999) besarnya nilai koefisien korelasi berganda (R) pada penelitian ini masuk pada range kuat $(0,60-0,799)$.

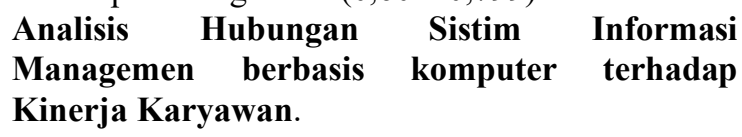

Berdasarkan hasil analisa yang telah dilaksanakan dapat diketahui bahwa: variabel perangkat keras atau Hardware, perangkat lunak atauSoftware, Database dan prosedur secara bersama-sama mempunyai hubungan yang bemakna terhadap kinerja karyawan Dinas Kepegawaian Daerah Kabupaten Sikka. Sedangkan untuk mengetahui variable yang mempunyai pengaruh paling dominan, dapat diketahui perangkat keras/Hardware adalah variabel yang memiliki pengaruh dominan dibandingakn variabel bebas lainnya.Jadi terbukti bahwa variable dominan dan variable -variabel lainnya memiliki pengaruh yang signifikan terhadap kinerja karyawan.

Sedangkan besaran koefisien Determinasi yang didapatkan dari hasil olah data adalah 0,931 yang berarti pengaruh sistim informasi managemen berbasis computer yang terdiri dari Hardware, Software, Database dan prosedur terhadap kinerja Pegawai Badan Kepegawaian Daerah Kabupaten Sikka adalah sebesar 93,1 \% dan sisanya $6,9 \%$ dipengaruhi oleh variable lain yang tidak diteliti. Gambaran hasil penelitian ini sesuai dengan pendapat Azhar Susanto (2004:3) bahwa, "kemampuan computer yang melahirkan berbagai kemungkinan aplikasi dapat membantu meningkatkan efisiensi dan efektifitas operasi suatu organisasi."

Instansi atau lembaga akan sulit mencapai tujuan yang diharapkan jika penerapan sistim informasi managemen berbasis computer kurang optimal, yaitu keadaan dimana komponen-komponen yang membentuk sistim managemen tidak sesuai dengan kebutuhan karyawan, sehingga karyawan akan sulit dalam menjalankan tugasnya sehari-hari.

Berdasarkan hasil empirik ditemukan adanya hubungan yang bermakna antara sistem informasi managemen (SIM) berbasis computer dengan kinerja pegawai Badan Kepegawaian Daerah 
Kabupaten Sikka. Untuk itu dalam meningkatkan kinerja pegawai pada Dinas Kepegawaian Daerah Kabupaten Sikka harus lebih menfokuskan pada aspek-aspek SIM berbasis computer karena dengan begitu diharapkan kinerja pegawai akan meningkat

\section{KESIMPULAN}

1. Berdasarkan hasil penelitian dapat diperoleh jawaban bahwa variabel SIM berbasis computer yaitu hardware, software, database, dan prosedur dapat meningkatkan kinerja pegawai Kantor Badan Kepegawaian Daerah Kabupaten Sikka. SIM berbasis komputer di lingkungan Dinas BKD Kabupaten Sikka telah berjalan dengan baik dan mendukung kinerja pegawai sehingga pegawai dapat menyelesaikan tugas dengan lebih baik.

2. Secara keseluruhan variabel-variabel bebas yang diteliti mempunyai pengaruh yang bermakna terhadap kinerja pegawai pada Kantor BKD Kabupaten Sikka. Namun secara terpisah terdapat variable bebas yang dominan terhadap kinerja pegawai, yaitu hardware. Variabelhardware mempunyaipengaruh yang paling kuat terhadap kinerja pegawai dikarenakan penggunaan perangkat keras terutama pada peran perangkat keras dalam memberikan kemudahan dan ketersediaan perangkat keras yang paling baru. Dengan adanya perangkat keras yang memadai maka tugas-tugas pegawai akan cepat diselesaikan dengan baik.

3. Kinerja pegawai Kantor Badan kepegawaian Kabupaten Sikka tergolong tinggi. Hal ini dapat ditunjukkan secara deskriptif dari indicator yang menunjang terutama kualitas kerja, kuantitas dan waktu kerja. Kinerja pegawai dapat ditingkatkan dengan pengaplikasian hardware, software, database dan prosedur. Dengan perangkat keras yang canggih dan mudah digunakan memudahkan operator computer melaksanakan tugas.

\section{DAFTAR PUSTAKA}

[1] Agus Mulyanto. 2009. Sistim Informasi Konsep dan Aplikasi.Pustaka Pelajar, Yogyakarta

[2] Arikunto, S. 2010. Prosedur penelitian : Suatu Pendekatan Praktik. (Edisi Revisi). Rineka Cipta, Jakarta

[3] Azhar Susanto.2005.Sistim Informasi Manajemen.Ghaila Indonesia, Jakarta.

[4] Davis, Gordon B. 1995. Sistim Informasi Manajemen, PT. Pustaka Binaman Pressindo,Jakarta.

[5] Davis, Gordon B, 2002. Kerangka Dasar: Sistim Informasi Manajemen, Bagian I Pengantar. Seri Manajemen. Cetakan Kedua Belas, Jakarta: PT. Pustaka Binawan Pressindo,Jakarta

[6] Harahap, Mannaria,2010.“Pengaruh Komputer Base Information Sistim (CBIS) Terhadap
Kinerja Karyawan Koperasi Agro Niaga (KAN) Jabung",Tesis Program Studi Manajemen-Program Pascasarjana, Universitas Merdeka, Malang.

[7] Harahap, Mannaria. 2010. Pengaruh Komputer Base Information Sistim (CBIS) Terhadap Kinerja Karyawan Koperasi Agro Niaga (KAN) Jabung.Tesis Program Pasca sarjana UNMER Malang. Tidak diterbitkan.

[8] Jogiyanto H.M, 1999, Analisis dan Disain Sistim Informasi, Andi, Yogyakarta.

[9] Keputusan Menteri Dalam Negeri Nomor : 17 Tahun 2000 Tentang Sistim Informasi Manajemen Kepegawaian Departemen Dalam Negeri Dan Pemerintah Daerah

[11] Masri Singarimbun \& Sofyan Effendi, 1995, Metode Penelitian Survei, Edisi Revisi, PT. Pustaka LP3ES, Jakarta.

[12] O’Brien, James A. dan George M. Marakas.(2010). Management Information Sistims. Eight Edition. New York : McGrawHill/Irwin

[13] Raymond McLeod,Jr. 2001. Sistim Informasi Edisi 7 Jilid 2. Prenhallindo, Jakarta

[14] Rivai Veithzal. 2005. Performance Appraisal Sistim Yang Tepat Untuk Menilai Kinerja Karyawan Dan Meningkatkan Daya Saing Perusahaan. PT. Raja Grafindo Persada, Jakarta.

[15] Rivai, Veithzal. 2009. Manajemen Sumber Daya Manusia Untuk Perusahaan Dari Teori ke Praktik. Jakarta: Raja Grafindo Persada, Jakarta

[16] Rivai Veithzal, 2014, Manajemen Sumber Daya Manusia Untuk Perusahaan Dari Teori dan Praktik, PT. RajaGrafindo Persada, Jakarta.

[17] Souhoka, Samuel. 2013. Evaluasi Penerapan Sistim Informasi MAnagemen (SIM) Berbasis Komputer Terhadap Peningkatan Kinerja Pegawai Badan Karyawan Dinas Perhubungan Provinsi Maluku Kota Ambon.Tesis. Program Pasca Sarjana UNMER MALANG. Tidak diterbitkan

[18] Sugiyono, 1997, Metode Penelitian Administrasi. CV Alfabeta, Bandung

[19] Sugiyono,2012. Metode Penelitian Bisnis. Cetakan ke enam belas CV Alfabeta, Bandung.

[20 Sunyoto, Danang. 2014. Sistim Informasi Manajemen Perspektif Organisasi CAPS(Center of Academic Publishing Service), Yogyakarta.

[21] Sulistyani Komalasari, Imam Hanafi, Endah Setyowati, 2014. Aplikasi Program Sistim Informasi Manajemen Kepegawaian (SIMPEG) ,Studi pada Badan Kepegawaian Daerah Kota Malang. Jurnal Administrasi Publik (JAP), Vol. 2, No. 4, Hal. 613-619. 